\title{
THE ROLE OF SPATIAL PLANNING IN THE INVESTMENT PROCESS IN POLAND AND SLOVENIA
}

\author{
Małgorzata Krajewska PhD \\ University of Technology and Life Sciences in Bydgoszcz, Poland \\ e-mail: gosiak@econ.umk.pl
}

Sabina Źróbek, prof.

University of Warmia and Mazury in Olsztyn, Poland

e-mail: zrobek@uwm.edu.pl

Maruška Šubic Kovač, prof.

University of Ljubljana, Slovenia

e-mail: maruska.subic-kovac@fgg.uni-lj.si

This paper is based on the hypothesis that: "Spatial planning should regulate spatial development, taking into account the public and private interests, and enabling the development of public and private investments in construction projects. Investors may be discouraged from construction on account of too small or too excessive a number of spatial implementation conditions (land use guidelines) in particular, where an adequate professional basis has not been provided"

This hypothesis has been verified by analyzing spatial planning processes in Poland and Slovenia, two countries whose centrally-planned economies (in Slovenia, this was called the socialist market economy) have been transformed into functioning market economies.

The main aim of this study was to discuss the significance of spatial planning documents in the investment process and their contribution to the preservation of spatial order. Special emphasis was placed on planning documents that allow construction in areas not covered by a local zoning plan. In Poland, the relevant document is the outline planning permission for development of land or property. Investors are required to prepare extensive source documents that are used by the (local) authorities for issuing outline permissions for the development of land and of property. Due to a lengthy procedure for obtaining outline planning permission, development is delayed and, as a consequence, investors are discouraged from building. In Slovenia, the relevant spatial plans at the local level include the municipal spatial plan, which set out the spatial implementation conditions and the detailed spatial plan. The spatial implementation conditions are the criteria and conditions for intervention as determined by the spatial planning document, in accordance with which the acquisition of building permits under regulations on construction is prepared. These can have a significant impact on the performance of the investment project. In some cases, such conditions even discourage investors from building, because they are not on an adequate professional basis.

The three examples discussed in this paper show that both too general and too precise spatial implementation conditions (land use guidelines) are unfavorable for investors and validate the hypothesis.

Key words: construction permits, spatial chaos, spatial planning in Poland and Slovenia.

JEL Classification: R30, R52, R58.

Citation: Krajewska M., Źróbek S., Šubic-Kovač M., 2014, The role of spatial planning in the investment process in Poland and Slovenia, Real Estate Management and Valuation, vol. 22, no. 2, s. 52-66.

DOI: $10.2478 /$ remav-2014-0017 


\section{Introduction}

As a regulatory measure, spatial planning can have various meanings in different countries. In nearly all countries that are members of the United Nations Economic Commission for Europe (UNECE), spatial planning is a key instrument for establishing long- and medium-term frameworks for territorial development, promoting rational spatial organization of land uses and reconciling competing policy goals. It aims to balance demands for development with the need to protect the environment, and to achieve social and economic objectives (ECE 2008). It is an instrument that aims to maintain a balance between the rights of owners or the so-called private interest and the larger public interest.

This study was motivated by a popular conviction that the Polish spatial planning system is undergoing a serious crisis (CIEŚLAK 2010), which is manifested by spatial chaos (BUCZEK 2011) and uncontrolled urbanization (Koncepcja... 2013). From this follows the hypothesis: "Spatial planning should regulate spatial development, taking into account the public and private interests, and enabling the development of public and private investments in construction projects. Investors may be discouraged from construction on account of too small or too excessive a number of spatial implementation conditions (land use guidelines) in particular, where an adequate professional basis has not been provided."This hypothesis has been tested by analysing the spatial planning processes (especially investment processes) in Poland and in Slovenia, two countries whose centrally-planned economies (in Slovenia, this was called the socialist market economy) have been transformed into functioning market economies.

\section{Methodology}

As the key instrument relevant to development and effective management, the spatial planning system delivers numerous benefits, mostly economic, but also social and environmental. An effective spatial planning system generates the following direct benefits for investors (ECE 2008):

- it creates spatial order by introducing clear and legible spatial structures,

- it enhances the stability of investments and improves investor confidence,

- it coordinates actions and investments to ensure maximum positive impact from the investment of resources, it is necessary to coordinate actions and investments in time and space,

- it facilitates the decisions to be made in a more efficient and consistent way,

- it generates demand for land plots zoned for development,

- it guarantees that economic functions are rationally distributed across different regions, including with regard to transport networks and labour markets,

- it supports the identification of environmental conditions which are (or are not) conducive to investment,

- it creates a framework for exercising ownership rights - buyers of property (including land zoned for development) acquire not only rights, but also obligations,

- it improves the quality of urban space and contributes to an increase in property value.

Spatial planning should thus provide certain benefits for investors as they are otherwise not going to be interested in investing.

Within the research, the analysis of spatial planning systems was performed, using the comparative method, and the impact of spatial planning on investment and deviation from planning regulation in Poland and in Slovenia, taking into account the possible differences in the social, economic and social conditions in each country. The design of a system for planning, implementation and control is dependent on the general attitude in the society to public involvement and steering. The focus in this article is on physical development, even though one must be well aware of the many relations between social, economic and physical conditions and that comprehensive planning must take this into consideration.

Another limitation is that we only superficially touch on sectorial planning systems. Focus is on the formal and statutory system, but we show that behind the formal facade different kinds of applications may exist in practice.

We do not go into detail concerning private planning and implementation of development projects. The focus is on the activities of public authorities: state, region, local government and community, whose goals may be established and the ways they are furthered by spatial planning and its implementation. 
In physical planning, ownership rights are most important as they determine who has the power to talk for the land and be responsible for implementation of plans. Relevant particulars are beyond the scope of this paper. Likewise, we abstain from analyzing in detail the official records which define ownership and other rights and also areas and boundaries for these rights, as well as other necessary information concerning land, are essential in a planning context. A good land information system is a basic factor for the development of efficient land planning systems. Early on most countries developed some kind of property records as a basis of land taxes.

\section{General information of Poland and Slovenia}

For information only we present hereinafter certain statistical indices of each country under discussion

Table 1

Selected geographic data for Poland and Slovenia

\begin{tabular}{ll}
\hline \multicolumn{1}{c}{ Poland } & \multicolumn{1}{c}{ Slovenia } \\
\hline Capital: Warsaw & Capital: Ljubljana \\
\hline Official language: Polish & Official language: Slovene \\
\hline Political system: parliamentary democracy & Political system: democratic republic \\
\hline Area: 312,679 km2 (70th in the world) & Area: 20,273 km2 (150th in the world) \\
\hline Population: 38.5 million (34th) & Population: 2.06 million (144th) \\
\hline EU accession date: 1 May 2004 & EU accession date: 1 May 2004 \\
\hline Currency: złoty (PLN, złoty) & Currency: Euro $(€)$ \\
\hline
\end{tabular}

Source: https://pl.wikipedia.org/wiki/Polska, http://pl.wikipedia.org/wiki/Słowenia, retrieved on: 8 July, 2013.

It is evident from Table 1 that the countries are comparable (they became the EU Member States at the same time), though essentially differing as regards their surface area and number of inhabitants. Poland is around 10 times bigger in surface area and has approximately 10 times as many inhabitants.

GDP per capita in 2012 in Slovenia was nearly twice that of Poland which, however, does not exhibit the current economic problems of Slovenia. Whilst Poland has a rather stable situation, Slovenia is currently in a financial and economic crisis, reflecting investment in real estate: in a lesser scope of investment into real estate, in the uninhabited and non-finalised real estate, a weak real estate market. Slovenian economists (FABJANČIČ et al 2013) are sure that Slovenian economy had irrespective of the global financial crisis - already been exhausted and over-extended at the time of its emergence.

In this paper, the element of financial and economic crisis will not be included in the comparison, as the role of spatial planning in the investment process is dealt with.

\section{Description of spatial planning systems in Poland and in Slovenia}

\subsection{Poland}

In Poland, the spatial planning concept does not have a statutory definition, but under the provisions of the National Spatial Development Concept 2030 -NSDC 20301 (Koncepcja... 2013), it is a management tool for formulating the goals and objectives of the National Spatial Development Policy, defining the manner in which they are implemented. The main goals of spatial planning are: to indicate opportunities for using specific features of a given area to achieve development objectives, to coordinate and determine the spatial distribution of planning activities to achieve synergy, to preserve territorial features that require protection, and to set the foundations for long-term sustainable development (Koncepcja... 2013).

In Poland, spatial planning is regulated by a number of legal documents, in particular the Act on Spatial Planning and Development of 27 March 2003, which sets out the type, scope and procedures for enacting planning documents at different levels of administration.

1 National Spatial Development Concept 2030, Polish Ministry of Regional Development, source: www.mrr.gov.pl 
In line with Polish legislation, land zoning decisions and planning permissions issued at all levels of administration, from national to local/municipal, should be guided by the principles of spatial order and sustainable development (ŹRÓBEK and ZACHAŚ 2005). Spatial order ${ }^{2}$ is defined as an arrangement of space that creates a harmonious whole and ensures that functional, social, economic, environmental, cultural, compositional and aesthetic considerations are taken into account in the planning process ${ }^{3}$.

The National Spatial Development Concept (NSDC) developed by the minister for regional development, is the key strategic document that addresses spatial planning and management in Poland. According to the Act on Spatial Planning and Development ${ }^{4}$ (Ustawa 2003), NSDC sets the goals for Poland's sustainable spatial planning policy based on environmental, cultural, social and economic considerations as detailed in other acts. The NSDC is approved by the Council of Ministers which determine the extent to which the concept will contribute to the development of government programs supporting investments that serve the public interest.

At the regional level, regional zoning plans are developed by the marshals of the respective Polish regions and approved by regional assemblies. They apply to the territory of the entire region and they account for the provisions of the NSDC and government programs ${ }^{5}$.

At the municipal level, spatial planning is a two-tier process (KRAJEWSKA 2011). The first tier - the municipal spatial planning policy, including local planning principles - is represented by the land use plan. The land use plan is developed by the mayor of a municipality or town. It accounts for the provisions of the NSDC and the regional development strategy set by the regional zoning plan. The land use plan is approved by the municipal council. It is a mandatory document, but its provisions are not part of municipal law. The land use plan covers areas situated within the administrative boundaries of a municipality. Its provisions are binding for municipal authorities in the process of developing local zoning plans.

The second tier is represented by the local zoning plan which sets out the terms on which the provisions of the land use plan should be implemented. The local zoning plan is developed by the mayor of a municipality or a town in accordance with the provisions of the land use plan, and is approved by the municipal council. The local zoning plan plays an important role in local spatial planning policy. However, municipalities are not legally required to develop local zoning plans for all territories in the municipality.

The outline planning permission for development of land and property is a supplementary document that is issued by the mayor of a municipality or a town in those municipalities that have not developed a local zoning plan (provided that it does not violate the provisions of other legal acts and complies with statutory requirements, including the principles of good neighbourhood design). Outline planning permission for development of land and property is issued on individual request, and it can take on one of the two forms: outline planning permission for public projects (investments that cater to the broad public interest) or outline planning permission (for the remaining projects). In municipalities that have not developed a local zoning plan, outline planning permission "replaces" the local zoning plan, and its provisions are binding on the local authorities issuing construction permits and property subdivision approvals.

The provisions of the Act on Spatial Planning and Development guarantee vertical cohesion between different tiers of the national spatial planning system.

In the Polish spatial planning system, the principle of spatial order that contributes to the preservation of a "harmonious whole" has been incorporated in professional planning documents, but only to the level of the local zoning plan, and the mutual relationship between planning documents are regulated statutorily only at that level. Detailed requirements and correlations between different tiers of the spatial planning system have not been specified by the legislature for the procedure of issuing outline planning permissions for development of land or property and outline planning permissions, as illustrated in Table 2, all arrows ending at the position 6.

\footnotetext{
2 Art. 1, section 2, point 1 of the Act on Spatial Planning and Development of 27 March 2003

3 Ibidem, art. 2, point

4 Ibidem, art. 47

${ }^{5}$ Ibidem, art. 39
} 
Types of planning documents in Poland and the correlations between them

\begin{tabular}{|c|c|c|}
\hline $\begin{array}{c}\text { Poland - administrative } \\
\text { division }\end{array}$ & $\begin{array}{l}\text { Competent planning } \\
\text { authority }\end{array}$ & Planning documents \\
\hline National level & $\begin{array}{l}\text { Ministry of Regional } \\
\text { Development }\end{array}$ & $\begin{array}{l}\text { 1. National Spatial } \\
\text { Concept (NSDC) } \\
\text { 2. Sectoral and government } \\
\text { programs }\end{array}$ \\
\hline Regional level & $\begin{array}{l}\text { regional assembly, } \\
\text { marshal of a region }\end{array}$ & $\begin{array}{l}\text { 3. Regional zoning plan } \\
\text { 4. Zoning plan of a metropolitan } \\
\text { area - as part of the regional } \\
\text { zoning plan }\end{array}$ \\
\hline County level & $\begin{array}{l}\text { county council, county } \\
\text { governor }\end{array}$ & $\begin{array}{l}\text { No guidelines pursuant to the } \\
\text { provisions of the Act on Spatial } \\
\text { Planning and Development }\end{array}$ \\
\hline Local level & $\begin{array}{l}\text { municipal council, } \\
\text { mayor of a municipality } \\
\text { or a town }\end{array}$ & $\begin{array}{l}\text { 5. Municipal land use plan } \\
\text { 6. Municipal zoning plan } \\
\text { 7. Outline planning permission for } \\
\text { development of land and } \\
\text { property: } \\
\text { - outline planning permission } \\
\text { for public projects } \\
\text { - outline planning permission }\end{array}$ \\
\hline
\end{tabular}

Source: Own elaboration based on the provisions of the Act on Spatial Planning and Development.

\subsection{Slovenia}

Before it was established as an independent state, Slovenia had a comprehensive social planning system, which contained, in addition to economic and social aspects, a spatial aspect. When Slovenia gained independence in 1990, a special law abolished the social planning. Only spatial components of the national and local social plans were in force until the adoption of new spatial planning and management regulations.

In 2002, the Spatial Development Strategy of Slovenia was first adopted, ensuring sustainable development. The Spatial Order of Slovenia sets out $-^{*}$ the rules for spatial planning and management with the aim of using them to provide the basis for a uniform method of town and landscape planning.

On 1 January 2003, following a transition period of several years, Slovenia adopted the new Spatial Planning Act (2002). The Spatial Planning Act governs inter alia the field of spatial planning and implementation measures in building land development in Slovenia. At the same time, a new construction act (the Construction Act 2002) was passed, which instead of two permits(a location (planning) permit and building permit) instituted a single permit - the new building permit. This applied until the new Spatial Planning Act (2007), had new parts relating to spatial planning and building development.

In the field of spatial planning and management, the State (Ministry of the Infrastructure and Spatial Planning of the Republic of Slovenia) prepares laws, policies, and other instruments, that are adopted by the National Assembly or the Government of the Republic of Slovenia. They define the spatial planning system and provide strategic spatial development objectives and guidelines. In addition to the spatial development laws and strategic documents, the state also has the authority to perform measures concerning spatial development activities and construction, which are of national significance.

The state uses laws and other strategic documents to provide frameworks for spatial planning at the regional and local levels and has also the responsibility to:

- conduct and implement land policy,

- maintain the spatial data system,

- develop and encourage professional work in spatial planning, and 
- participate in the matters of spatial planning and management at the international level.

Local communities (municipalities) have the right to undertake spatial management and planning of their territories, with exception of spatial development activities which are under direct jurisdiction of the state.

Thus, spatial planning is conducted in relatively small local communities, which normally do not have enough professional staff available for operations in this field, and in their spatial plans, they need to take into account polycentric spatial development in line with the urban system. Planners (POGAČNIK 2013) underline that it is important to define the urban system as a part of the Strategic Spatial Plan of the Republic of Slovenia.

A consequence of the lack of relevant professional bases is the fact that the demand for building land is overestimated in these plans. Analyses have shown (RuS 2011) that such building land is sufficient for 90 years at current rates. As the financial contributions are linked to such building land, this should stimulate land owners to sell the land for construction. The last land owner shall (hypothetically speaking) sell such land only in the ninetieth year. In addition, the spatial plans are not realized in many instances also due to the considerable costs of land development on the side of the local community as well as on the side of the investors.

The Spatial Planning Act (2007) regulates spatial planning as part of physical planning so that it lays down types of spatial planning document, their content and mutual relations, and procedures for their drafting and adoption.

Spatial planning is in the public interest. The objective of spatial planning is to enable coherent spatial development by the consideration and harmonisation of different development needs and interests with public benefits in the areas of environmental protection, the conservation of the natural and cultural heritage, the protection of natural resources, defence and protection against natural and other disasters.

The state:

1) Sets targets for spatial development at state level,

2) Determines references and guidelines for planning spatial arrangements at all levels,

3) Plans spatial arrangements of national importance, and

4) Supervises spatial planning at the municipal level.

The local community:

1) Determines references and guidelines for the spatial development of the municipality,

2) Determines the use of space and conditions for intervention, and

3) Plans spatial arrangements of local importance.

The individual planning acts/documents at the different levels are shown in Table 3.

Table 3

Administrative division of Slovenia and types of planning documents at different levels

\begin{tabular}{lll}
\hline $\begin{array}{l}\text { Slovenia } \\
\text { administrative } \\
\text { division }\end{array}$ & $\begin{array}{l}\text { The institution responsible for } \\
\text { planning }\end{array}$ & Planning documents (studies) \\
\hline National level & $\begin{array}{l}\text { Ministry of Infrastructure and Spatial } \\
\text { Planning of the Republic of Slovenia }\end{array}$ & $\begin{array}{l}\text { 1. National strategic spatial plan } \\
\text { 2. National spatial plan }\end{array}$ \\
\hline Regional level & $\begin{array}{l}\text { Slovenia has not yet formally } \\
\text { established a regional administrative } \\
\text { level. }\end{array}$ & $\begin{array}{l}\text { 3. Inter-municipal spatial planning } \\
\text { document as a "regional spatial plan" }\end{array}$ \\
\hline Local level & $\begin{array}{l}\text { Local community; municipal council, } \\
\text { mayor }\end{array}$ & $\begin{array}{l}\text { 4. Municipal spatial plan with the strategic } \\
\text { and operational part. }\end{array}$ \\
& & $\begin{array}{l}\text { 5. Detailed municipal spatial plan } \\
\text { 6. Urban plan }\end{array}$ \\
\hline
\end{tabular}

Source: Own study based on Spatial Planning Act 2007.

For the areas of individual towns or settlements of urban importance and other development centres, which will become towns or settlements of urban importance, an urban plan may be adopted.

The Spatial Planning Act defines the relations between spatial planning documents:

- The national spatial plan must not be contrary to the national strategic spatial plan, except in 
the case of planning spatial arrangements for clean-up operations after natural or other disasters.

- The regional spatial plan must not be contrary to national spatial planning documents.

- Municipal spatial planning documents must not be contrary to national spatial planning documents and regional spatial plans.

- Municipal detailed spatial plans must comply with the municipal spatial plan.

- Municipal spatial plans must not be contrary to municipal strategic spatial plans.

In 2010, the Act regarding the siting of spatial arrangements of national significance in physical space was passed, which regulates the national level of spatial planning in the Republic of Slovenia.

This Act (as amended and supplemented) sets out spatial arrangements of national significance, regulates the content and procedure for the preparation of the National Spatial Plan, and also regulates permission for siting in physical space and certain questions regarding provisional implementation measures for the protection of spatial planning and management in the area of plans, the determination of boundaries and land allotment in the area of plans, and the acquisition of real estate and rights over such real estate for the implementation of spatial arrangements arranged with plans.

The changes should enable the swifter preparation of documentation for the acquisition of the EU financing, and, in particular, increased responsibility of the investor for the professional, efficient and timely preparation of the national spatial plan and for the consistent unification of the spatial and investment documentations so as to avoid duplication and the lack of clarity.

The two spatial planning systems presented here play an important role in the investment or construction process.

\section{Local planning and investment - building process in Poland}

Every construction process begins with the determination of planning requirements applicable to a given area, and it comprises two key stages:

Stage 1: The investor acquires information about the type of planning documents available for the area in question, in particular the availability of a local zoning plan.

Stage 2a: The investor becomes familiar with the provisions of planning documents and planning guidelines for investment projects in a given area.

Stage $2 b$ : The investor applies to municipal authorities for outline planning permission for development of land or property which sets out the conditions and requirements for building and managing future property.

The investor is required to document his right to the land on which property will be developed. The above applies to undeveloped land as well as land occupied by property that will be expanded, adapted or reconstructed during the project. Properties where improvements are to be introduced to or on the land (where structures will be built or where the existing structures will be modified) are collectively referred to as development properties in the literature. The manner and type of development and the success of the entire undertaking are determined by various factors, including local planning requirements and development strategies. In the best-case scenario, planning requirements for the property in question are clearly formulated in the local zoning plan (Stages 1 and 2a), which ensures the preservation of spatial order and the observance of sustainable development principles on the ground. The local zoning plan is the key document for preparing the construction design and applying for the construction permit.

In the following stage of the investment process, the investor can subdivide the land plot in accordance with the provisions of the local zoning plan and prepare the construction design. This mode of development, which relies on the provisions of the local zoning plan, is most desirable.

Unfortunately, the vast majority of Polish municipalities have not developed local zoning plans that fully cover their territory. In 2010, the national average was $26 \%$ and the average for cities was 35\% (Koncepcja... 2013).

Despite this, territories which are not covered by local zoning plans are still available for investment. In the absence of a local zoning plan, investors can apply for outline planning permission for development of land or property (Stages 1 and $2 b$ ) that constitutes a formal basis for applying for a construction permit. Outline planning permission granted by local authorities may violate the principles of spatial order because contrary to the applicable legal acts, the provisions of the municipal land use plan do not have to be taken into account in the process of developing and issuing outline 
planning permissions (the links between the two documents are presented in Table 2, but they apply only at the level of local zoning plan).

Case 1 describes the realization of investment process in Poland according to two legal paths: Stage 2a) land development on the basis of local plan , because in this case a local plan actually exists; Stage $2 \mathrm{~b}$ ) simulation assuming that local plan does not exists and thus land development will be based on investor's directions and the local authority's permission.

Case 1. The local zoning plan for the Linie Housing Estate with the estimated area of $26 \mathrm{ha}^{6}$, situated in the municipality of Dąbrowa Chełmińska, Bydgoszcz county, is presented in Fig. 1. Land plot No. 279 is marked in green and the area that would be analyzed by the local authorities in the process of issuing an outline planning permission (in the absence of a local zoning plan) is marked in orange.

Stage 2a) The following information in the local zoning plan is of essence for an investor planning to develop land plot No. 279 in Dąbrowa Chełmińska (marked in green):

1) land plot No. 279 comprises four zoning districts:

- $4 \mathrm{MN}, 27 \mathrm{MN}$ - land zoned for single-family home construction; no other planning functions are permitted,

- 18KDW - internal public road - road for motor and pedestrian traffic,

- $11 \mathrm{KPL}$ - local public road;

2) building construction tolerances are specified;

3) the land plot can be subdivided into three plots for residential construction;

4) the descriptive part of the local zoning plan contains detailed planning and development requirements.

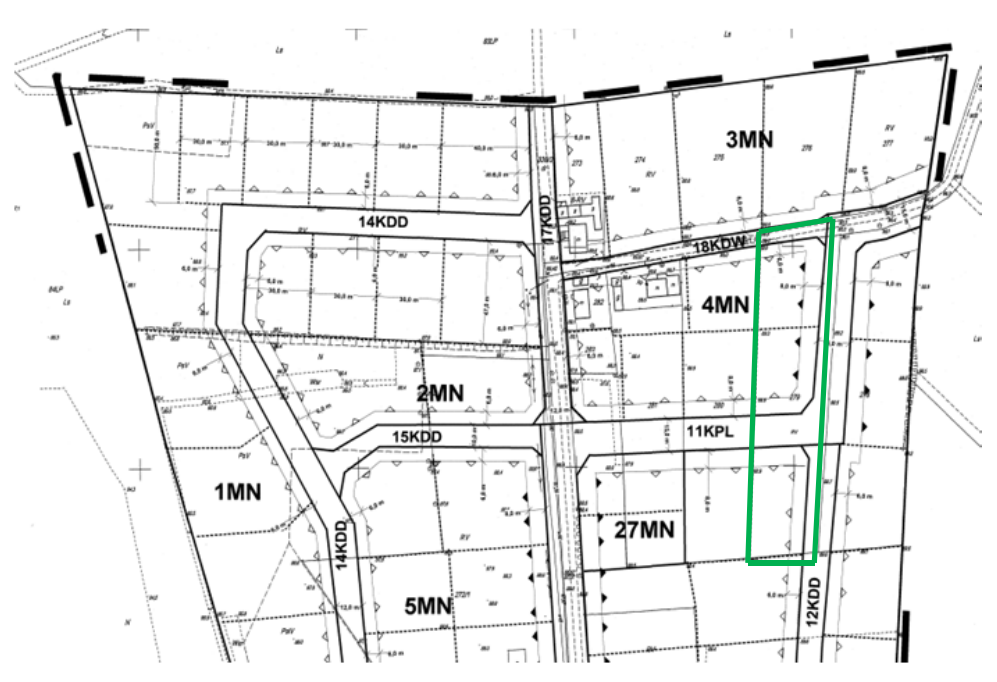

\begin{tabular}{|c|c|}
\hline & Legend: \\
\hline$\nabla$ & maximum impassable building line \\
\hline & existing building lines \\
\hline & $\begin{array}{l}\text { dividing areas for different purposes } \\
\text { different development rules }\end{array}$ \\
\hline $\mathrm{MN}$ & residential area \\
\hline KPL & public road district - local \\
\hline KDD & municipal public road - Access \\
\hline KDW & internal road of charge \\
\hline & analyzed plot No. 279 \\
\hline
\end{tabular}

Fig. 1. Section of the local zoning plan of Dąbrowa Chełmińska. Source:

http:/ / www.bip.dabrowachelminska.lo.pl/index.php?app=uchwaly\&nid=1446, retrieved on 30 October 2013.

In the above example, the local zoning plan contributes to the preservation of spatial order by indicating the location of roads for the entire area and proposing various options for subdividing the area into plots for residential construction. The investor has to take into account that fragments of land plot No. 279 have been zoned for public and internal roads that will create access to the entire housing estate. This information is clearly communicated to the investor, and since the local zoning plan constitutes an act of law, the investor is under legal obligation to transfer a part of his property for the construction of public amenities (for compensation).

6 Local zoning plan for the LINIE HOUSING ESTATE in Dąbrowa Chełmińska, approved by Resolution XIX/133/08 of the Municipal Council of Dąbrowa Chełmińska of 26 September 2008 (Official Journal of the Region of Kujawy and Pomorze of 4 November 2008, No. 139, item 2186). 
Stage 2b/ If a local zoning plan were not available for the analyzed land plot No. 279 in Dąbrowa Chełmińska, the investor would probably be entitled to outline planning permission for development of land or property, issued based on the principles of good neighborhood design that are set out in art. 61 of the Act on Spatial Planning and Development (Ustawa 2003):

1) at least one adjacent land plot accessible via the same public road is built up in a manner that supports the determination of functional requirements, parameters, planning features and indicators, including the size and architectural form of buildings, building line and land-use intensity for new buildings,

2) the property has access to a public road,

3) the existing or planned public utilities cater for the needs of the planned construction undertaking,

4) the property does not constitute agricultural land or a forest where a separate permission is required for development projects that are not associated with agricultural or forest production, or a relevant permission has been granted to the property in question,

5) the outline planning permission complies with the provisions of other legal acts.

Land plot No. 279 meets all of the above conditions.

In the process of developing the outline planning permission for development of land and property, the planning authorities would analyze land plot No. 279 and its immediate surroundings covering the area of approximately 1.5 ha (three times the width of the plot's front side, pursuant to the provisions of $\$ 3$ of Regulation 2003) (Rozporządzenie 2003).

In the analyzed example, the analyzed area would be roughly identical to the area indicated in the master map in Fig. 2 (the area was marked in orange in the local zoning plan in Fig. 1).

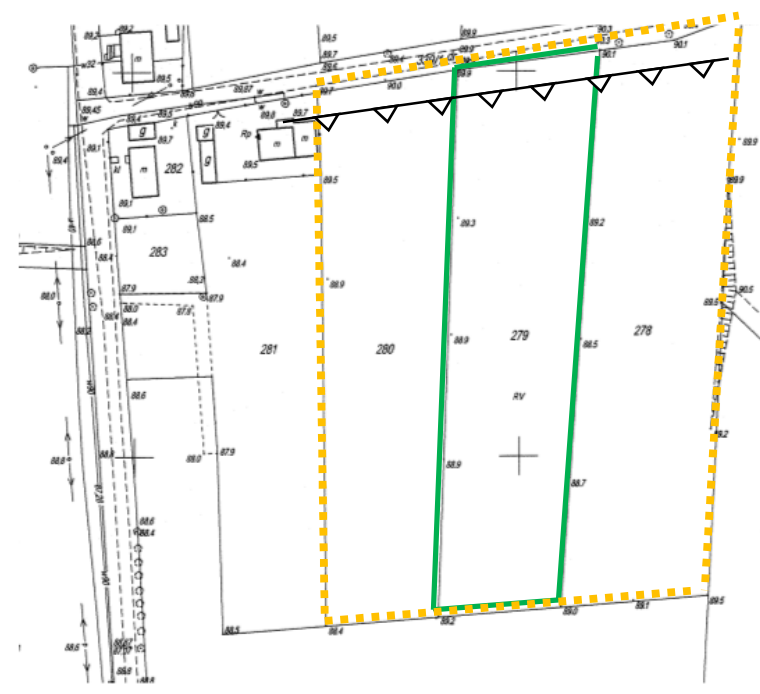

Legend

- analyzed plot No. 279

$n=$ area that would be subject to analysis if the local plan was not in existence

$\checkmark \vee \vee$ possible line of development

Fig. 2. Analysis area for plot number 279 , if local spatial development plan does not exist. Source: own studies

Above mentioned example clearly presents a situation, where investment process is based only on WZiZT and does not solve problems of urban composition for whole area, but only for its part (coloured in yellow) and therefore projects of communication layout are partial as well.- Lines delimiting local and regional roads and marking other technical infrastructure are not traced. Access to plot 279 from a public road is possible only from one side, the existing road. Therefore, development is legally possible only in the front part of the plot, on prolongation of neighboring plot number 281's development line. Such a situation lays out the area only partially, without connections with the whole area described in Stage 2a. From the investor's point of view, the process of achieving the outline planning permission for development of land and property (WZiZT) is time-consuming and delays real estate development. It results from the necessity of preparing a comprehensive set of information, which is used by local authorities for analysis, preparation of directions and eventually decision. This decision opens investment possibilities for real estate and includes investor's suggestions. However, it cannot realize the rules of spatial order and sustainable development.

An investor applying for outline planning permission for development of land or property should 
develop a preliminary property development concept with a specification of the technical parameters of buildings and structures. The investor is also expected to acquire the relevant maps, approvals for connections to the power grid, water supply and sewer systems as well as applicable environmental approvals. This is a time-consuming and costly process which requires the participation of licensed professionals. Stamp duty is charged on the application for outline planning permission and the waiting period can be as long as two months, provided that the investor is not asked to provide additional documents and the application process is not suspended. The investment process can be fraught with numerous problems in areas that are not covered by a local zoning plan.

In Polish judicial practice (BUCZEK 2011) the predominant view is that outline planning permissions for development of land or property are generally not influenced by local planning policy defined in the municipal land use plan. As a result, the majority of construction permits (more than 50\% according to NSDC 2030) are not issued based on local zoning plans that guarantee conformance with municipal land use plans, but are based on administrative decisions which were to be used only under extraordinary circumstances. The above trend was also noted by Hełdak (2010) and Borowska (2011). Outline planning permissions for development of land and property do not support comprehensive planning, and the excessive use of this instrument can obstruct rational urban development, functional zoning or the introduction of building height limits. According to Karwińska (2008) absence of local zoning plans significantly compromises spatial and landscape cohesion, not only at present, but also for the future. The lack of clear zoning guidelines promotes ambivalence and uncertainty in urban planning. Outline planning permissions are temporary measures that can be legally applied by the local authorities, but they have negative consequences for spatial planning.

Thus, too general guidelines on land use regarding the realization of construction investment will not encourage investors to build on such sites simply due to a large number of additional documents which need to be procured. At the same time, the above example and the conclusions formulated by NSDC 2030-Objective 6 indicate that the present spatial planning system, in particular at the local level, does not prevent random or dispersed development. Investments that are approved for execution under outline planning permission may be inconsistent with local planning strategies and do not contribute to the preservation of spatial order.

\section{Local planning and investment - the building process in Slovenia}

The construction of a new works, the reconstruction of works, replacement construction and the removal of a works may commence on the basis of a building permit that is deemed final in legal terms. The building permit is (Construction Act 2002) an administrative decision under which the relevant administrative body allows such execution of works and prescribes the specific conditions that must be observed during execution of works, after having found that the intended construction is in accordance with the spatial planning document, that the works will fulfil the essential requirements, and that the intended execution of works will not prejudice the rights of third parties or the public good.

Building permits are issued for:

- demanding works,

- less demanding works,

- simple works.

An application for acquisition of a building permit shall be filed by the investor with the substantively competent administrative authority for the construction and building matters (ministry or administrative unit).

The work's compliance with spatial planning documents shall be ensured through project design, in the procedure for issuing the building permit, through construction and the execution of works, in the procedure for issuing the permit of use, and through the use of the works or premises. It is necessary to design, construct or reconstruct and use works so that they comply with spatial planning documents.

This is verified in a special part of the project for acquisition of building permit, which is part of application for acquisition of building permit, and in particular the site plan from the relevant spatial plan showing the building plot, the site of the works on the land, its size, intended purpose of use, form and distance from neighbouring parcels, and the municipal utility connections if such are envisaged and the opinions added to the location plan by the relevant project approving authorities, 
including a description of how to apply them in the formulation of the project.

Important factors are the spatial implementation conditions, which are defined in the municipal spatial plan.

For each spatial arrangement, spatial implementing conditions shall be determined in the plan which shall determine:

- Conditions with regard to the intended use of activities affecting the environment, their location, size and design,

- Conditions with regard to transport and service hubs or the transposition of public infrastructure and constructed public assets and connecting spatial arrangements to them,

- Criteria and conditions for land allotment,

- Conditions for the integrated conservation of cultural heritage, nature conservation, environmental protection and natural assets, water management, human health protection, defence of the state, and protection against natural and other disasters,

- Stages of the implementation of the spatial arrangement, and

- Other conditions and requirements for the implementation of the spatial plan.

The size of deviations from functional, design and technical solutions, which are permissible in the preparation of a project for the obtaining of a building permit in accordance with regulations regulating a construction or a mining project in accordance with regulations regulating mining, may be determined by the spatial plan when new solutions within the framework of deviations do not change the planned visual appearance of the area, do not degrade living and working conditions in the zone of the spatial plan or in neighbouring areas, and when these solutions are not contrary to the public interest. The project's consenting authorities, whose responsibilities are interfered with by these deviations, must agree with permissible deviations.

Spatial implementing conditions may be defined for the size of facilities for the plot intended for construction, as for instance:

Factor of floor space index shall be defined as the ratio between the gross floor area of a facility and the entire surface of the building plot. Gross floor area of the facility is the total area of all the storeys of the facility above and underneath the terrain level.

Factor of built-up surface of a plot intended for construction is defined as the ratio between the built-up surface (covered area by a building) and the entire surface of the plot intended for construction.

Factor of building volume shall be defined as the ratio between the gross volume of the facility and the surface of the entire plot intended for construction. The gross volume of facility is the gross floor area of the facility multiplied by the mean height of the facility above the terrain level.

Share of open residential surfaces is expressed as percentage of open residential areas of the possible gross storey areas in relation to the building plot exploitation. Open residential surfaces shall be deemed the green surfaces and plastered surfaces intended for the outdoor living and which do not serve as traffic surfaces or communal functional surfaces (as for instance, accesses, driveways, parking spaces, areas for ecological islands).

These factors (indices) are defined in the municipal spatial plan. The problem is that frequently they are defined without any preliminary analysis. Thus, a) certain of these factors are inappropriate or even in collision with the principles of the Spatial Planning Act (Case 2) and b) have a significant impact on the performance of the investment project, or in some cases, such conditions even discourage the investors from building (Case 3).

Case 2: The Spatial Planning Act links the definition of sustainable spatial development with the rational land use. In the spatial plan of the Municipality of Ljubljana, spatial implementing conditions are laid down, including:

Table 4

Example of detailed spatial implementing conditions for the individual units of regulation. Implementing spatial plan of the Municipality of Ljubljana, supplemented draft

\begin{tabular}{ll}
\hline \multicolumn{1}{c}{ Unit of regulation: BC - 501} & No conditions \\
\hline Floor Space Index (FSI) (maximum) & 30 \\
\hline $\begin{array}{l}\text { Factor of built-up surface of a plot intended for } \\
\text { construction (maximum \%) }\end{array}$ & \\
\hline
\end{tabular}


Factor of open residential surfaces (minimum \%)

Urban planning conditions

35

Minimum size of building plot amounts to 600 $\mathrm{m} 2$. New facilities shall be oriented in parallel to the road, according to the historic buildingconstruction structure.

The existing built-up surface factors in the examples discussed have been defined as too high from the point of view of rational land use.

Case 3: Restrictions of spatial acts/documents affect investment profits. Profits depend on the characteristics of the location (DUŠIč 2008). Thus, it is most important to analyse already within the procedure of land use definition, which types of buildings and which spatial implementing conditions are to be determined so as to enable the success of real estate projects in this area. Zajc (2001) analysed the impacts of spatial implementing conditions on the success of investments in real estate projects in the suburbs of the City of Ljubljana, namely, in a land of the surface of $9,395 \mathrm{~m}^{2}$. He took into account the existing spatial implementing conditions of the land under discussion, as follows:

- Land use: residential building construction,

- Type of building construction: construction of single-apartment houses, exceptionally of double-apartment houses - duplex houses,

- Land built-up surface factor: $40 \%$,

- Distances from the road: $5 \mathrm{~m}$,

- Distance from the lot limits: $4 \mathrm{~m}$,

- Road for local access: minimum $3.5 \mathrm{~m}$,

- Distance from waterway: $10 \mathrm{~m}$,

- Limitations of technical infrastructure,

- Limitations of the building plot: 400-600 $\mathrm{m}^{2}$,

- Limitations as to the net residential surface: $160-250 \mathrm{~m}^{2}$.

He took into account several options of built-up surface in the area under discussion, with singleapartment houses and a single example of double-apartment houses - duplexes.

He found that the spatial implemention conditions, in particular a certain type of building and the factor of built-up surface of land impacted on the success of the real estate projects. In such a case, no option of real estate project was a success. Thus, he identified, why the investor in a neighbouring building plot constructed a business-residential facility of several storeys, irrespective of the fact of whether the construction was legal or not.

Already in the process of spatial planning, the spatial planners should prepare a simulation of real estate project development in an area with the planned land use, taking into account the direct and indirect expenses and profits, or weighting the public against the private interest and seeking a response to the question of public benefit on the one side, and of the effectiveness of the (private) investment project on the other side. However, such simulation of real estate projects is not feasible in Slovenia as there is no appropriate data to hand (ŠUBIC KOVAČ et al 2008).

All three cases show that both too general and too precise spatial implementation conditions (land use guidelines) are unfavorable for investors: on the one hand due to acquisition of a large number of additional documents for the construction, the time for obtaining a building permit is too long, on the other hand spatial implementation conditions, that are not based on professional bases, impact on the realization of a normal profit.

\section{Comparison and conclusions}

The influence of the European Union on spatial planning systems, policies and processes in the member states is steadily increasing. This is evident also from the analysis in this paper. An overall framework (principles) of spatial planning, laid down in the legislation, is similar in Poland and in Slovenia. Differences exist in the particulars and in spatial planning practice.

In both the countries under discussion, in Poland as well as in Slovenia, there exists the power of the local authority to decide if, where, when and how a development may take place.

In Poland, there is a lack of clear zoning guidelines that promotes the ambivalence and uncertainty in urban planning. In Slovenia, there is not so much the problem of a lack of clear zoning guidelines, but rather of a lack of professional bases for the development of zoning guidelines, in particular, as to taking into account economic aspects in defining the spatial implementing conditions, which shall be 
taken into account for the granting of a building permit. The lack of clear zoning guidelines and also inadequate spatial implementing conditions may deter investors' interest in construction.

Table 5

The key objectives of spatial planning systems in Poland and Slovenia and their role in the urban development process are presented below

\begin{tabular}{l} 
Poland \\
\hline - the spatial planning system is decentralized, \\
and it is regulated by a single legal act (Act on \\
Spatial Planning and Development), \\
- spatial planning activities have to promote \\
sustainable development, contribute to the \\
preservation of spatial order and the \\
protection of public interest, \\
- the spatial planning system is three-tiered, \\
and the relevant decisions are made at the \\
national, regional and local (municipal) level, \\
- the preservation of spatial order is a statutory \\
obligation of municipal authorities, \\
- all 'old' local plans from socialist economy, \\
elaborated before 01.01.1995, lost their legal \\
force 31.12.2003 (they do not exist in planning \\
decisions),
\end{tabular}

- statutory provisions guarantee the cohesiveness of the spatial planning system, but only to the level of the local zoning plan,

- investors can apply for a construction permit based on: 1/ the provisions of the local zoning plan (the most desirable case scenario which ensures compliance with the objectives of the spatial planning system), or 2/ outline planning permission for development land or property,

- the procedure of issuing outline planning permissions is not legally coordinated with the provisions of municipal land use plans,

- outline planning permission for development of land or property can contribute to random and uncoordinated development permissions may be issued simultaneously to several investors who propose different development concepts. The outline planning permission remains valid until the first investor obtains a construction permit,

- more than $50 \%$ of construction permits are issued based on the provisions of outline planning permissions, which contributes to planning chaos,

*) The content of spatial plans of the previous socio-economic system in the Republic of Slovenia is not the subject of analysis in this article. However, it needs to be pointed out that none of the "old" spatial plans is comparable to the spatial plans of the other former socialist countries.

It should be stressed in addition that guidelines only, which have been established in the spatial plan on a sound professional basis, may promote spatial development in a desired direction, as well as sustainable development. Any individual solutions, occurring during the acquisition of a building permit (Poland, Case 1, Stage 2b), or the inadequately professionally established spatial implementation conditions (Slovenia, Case 2 and Case 3), may disrupt any tendency towards 
sustainable development.

Investment processes that strictly conform to the provisions of planning documents promote sustainable development and contribute to the preservation of spatial order. Any other solutions that rely on administrative decisions or temporary permits distort the spatial planning system. They create investment opportunities, but investors are required to prepare extensive source documents that are used by the (local) authorities to issue outline permissions for development of land and property. Polish urban planners have proposed many solutions aiming at eliminating outline planning permissions and introducing (in areas not covered by local zoning plans) general planning standards that will contribute to the preservation of spatial order and will shorten the investment preparation period.

In Slovenia as well, there prevails the general opinion that the procedures for the acquisition of building permits are too long, where it is highlighted at the same time that the professional aspect are not necessarily curtailed within the shortened procedures. Among the reasons for the relatively prolonged procedures are the complaints by the participants in the procedure of acquisition of building permits. These are on account of the inaccuracy and unreliability of spatial implemention conditions of the spatial plan, which need to be taken into account in the acquisition of building permits.

\section{References}

Act regarding the siting of spatial arrangements of national significance in physical space, Official Gazette of the Republic of Slovenia No. 80/2010. (106/2010, 57/2012).

BOROWSKA M., 2011, Procesy budowlane w Łodzi w sytuacji braku miejscowych planów zagospodarowania przestrzennego (Physical development in Łódź in the situaation of missing the physical plans) ACTA SCIENTIARUM POLONORUM ADMINISTRATIO LOCORUM, 10 (3).

BUCZEK G., 2011, Opracowania planistyczne jako narzędzia ksztattowania ładu przestrzennego. (Planning documents as a tool for shaping the spatial order) (P) MAT. KONF. XX KRAJOWEJ KONFERENCJI RZECZOZNAWCÓW MAJĄTKOWYCH, KATOWICE, PP. 127-155.

CIEŚLAK I., 2010, Analiza systemu planowania przestrzennego we Francji w nawiązaniu do systemu polskiego, (A comparative analysis of the spatial planniung system in France and in Poland) ACTA SCIENTIARUM POLONORUM ADMINISTRATIO LOCORUM, 9 (2).

Construction Act, 2002, Official Gazette of the Republic of Slovenia No. 110/2002, 97/2003, 41/2004ZVO-1, 45/2004, 47/2004, 62/2004, 102/2004-UPB1 (14/2005), 92/2005-ZJC-B, 93/2005-ZVMS, 111/2005, 120/2006, 126/2007, 57/2009, 108/2009, 61/2010-ZRud-1 (62/2010), 20/2011, 57/2012, 101/2013-ZDavNepr, 110/2013.

DušIČ L., 2008, The impact of spatial planning conditions on the effectiveness of investments in real estate, UNIVERSITY OF LJUBLJANA, FACULTY OF CIVIL AND GEODETIC ENGINEERING, LJUBLJANA.

ECE/HBP/146. SPATIAL PLANNING KEy INSTRUMENT FOR DEVELOPMENT AND EFFECTIVE GOVERNANCE

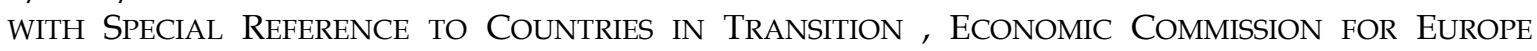
GENEVA, UNITED NATIONS, 2008.

FABJANČIČ $\quad$ Z., GRAHEK $\quad$ A., 4.10 .2013 , HTTP:/ /WWW.SIOL.NET/NOVICE/GOSPODARSTVO/2013/10/BI_BILA_SLOVENIJA_V_KRIZI_TUDI_BREZ_G LOBALNE_KRIZE.ASPX

HeŁDAK M., 2010, Rozwój przestrzenny zabudowy w strefie dużych miast (Building development in suburban areas), ACTA SCIENTIARUM POLONORUM ADMINISTRATIO LOCORUM, 9 (1).

KARWIŃSKA A., 2008, Gospodarka przestrzenna. Uwarunkowania spoteczno-kulturowe. (Spatial economy. Socio-cultural conditions) PWN WARSZAWA, Key INSTRUMENT fOR DEVELOPMENT AND EFFECTIVE GOVERnANCE With SPECial REFERENCE to COUNTRIES In TRANSITION, United NATIONS, NeW YORK AND GENEVA.

Koncepcja Przestrzennego Zagospodarowania Kraju 2030, Ministerstwo Rozwoju Regionalnego, (National Spatial Development Concept 2030) Poland, www.mrr.gov.pl, access: 05.07.2013r.

KRAJEWSKA M., 2011, Planning Conditions and the Market Value of Real Estate [IN:] INVESTMENT ON THE REAL ESTATE MARKET, ED. E. SIEMIŃSKA, WYDAWNictWo NAUKOWE UMK, ISBN: 978-83-231-2616-4, TORUŃ 2011, S. 63-99.

PAGON M., 2013, The influence of the spatial implementing conditions on the success of real estate project, UNIVERSITY OF LJUBLJANA, FACULTY OF CIVIL AND GEODETIC ENGINEERING, LJUBLJANA. 
POGAČNIK A., Proposal of changes in the urban system of Slovenia, Geodetski vestnik, ISSN 0351-0271. 2013, P. 97- 111, HTTP:/ /GEODETSKI-VESTNIK.COM/CMS/SL/PREJSNJE-STEVILKE/18-OBJAVE/19-GV-57-1

Rozporzadzenie Ministra Infrastruktury z dnia 26 sierpnia 2003 r. w sprawie sposobu ustalania wymagan dotyczacych nowej zabudowy i zagospodarowania terenu (Dz. U. Nr 164/2003 poz. 1588) (Regulation of the minister of infrastructure of 26 august 2003 on the method of determining the requirements of new construction and land development, Journal Of Laws, 2003, No 164, Item 1588)

Rus S., 2011, Assessment of required building land area in the municipality of Ribnica in the period 2010-2015. LJUBLJANA: UNIVERSITY OF LJUBLJANA, FACULTY OF CIVIL AND GEODETIC ENGINEERING.

Spatial Planning Act, 2002, Official Gazette of the Republic of Slovenia No. 110/2002. (8/2003), 58/2003-ZZK-1, 33/2007-ZPNačrt, 108/2009-ZGO-1C, 79/2010, 80/2010-ZUPUDPP (106/2010).

Spatial Planning Act, 2007, Official Gazette of the Republic of Slovenia No. 33/2007, 70/2008-ZVO-1B, 108/2009, 80/2010-ZUPUDPP (106/2010), 43/2011-ZKZ-C，57/2012，57/2012-ZUPUDPP-A, $109 / 2012,35 / 2013$.

ŠUBIC KOVAČ M. RAKAR A., Information required for single real estate valuation. GEODETSKI VESTNIK, ISSN 0351-0271. 2008, P. 706-715, HTTP://WWW.GEODETSKI-VESTNIK.COM/52/4/GV52-4_706-715.PDF.

Ustawa z dnia 27 marca 2003 r. o planowaniu i zagospodarowaniu przestrzennym (Dz.U.Nr 80/2003, poz. 717 z późn. zm) (Act on Spatial planning and development of 27 March 2003, Journal of Laws, 2003, No 80, item 717, as amended)

ZAJC K., 2001, Analysis of economic reasonability of various housing construction on relevant building land within the community of Dol. UnIVERSITY OF LJUBLJANA, FACUlTY OF CIVIL AND GEODETIC ENGINEERING, LJUBLJANA.

ŹRÓBEK S., ZACHAŚ M., 2005, The analysis of conflicts concerning urban area use: a case of Olsztyn (Poland), INTERNATIONAL JOURNAL OF STRATEGIC PROPERTY MANAGEMENT, 233-246. 